Vol. 19 (2010): 144-159.

\title{
Climatic potential and risks for apple growing by 2040
}

\author{
Timo Kaukoranta*, Risto Tahvonen and Arto Ylämäki \\ MTT Agrifood Research Finland, Plant Production Research, FI-31600 Jokioinen, Finland, \\ *email: timo.kaukoranta@mtt.fi
}

The impact of climatic change in 1971-2040 on the potential production areas and risks to nine apple cultivars (Malus domestica Borkh.) was studied over continental Finland using agro-climatic indices and gridded daily mean $\left(\mathrm{T}_{\mathrm{m}}\right)$ and minimum temperatures from the Rossby Centre regional atmospheric climate model (RCA3) with SRES A2. Point data on daily minimum temperatures from 14 weather stations and low and high warming scenarios were also used. From the 1970's to the present day, the areas of successful maturing of fruits have strongly expanded northwards. It is predicted that in 2011-2040, the warming of climate will allow expansion of commercial production in the south-eastern lake area, and a wider selection of cultivars for home gardens up to latitudes $65-66^{\circ} \mathrm{N}$. Risk of extremely low temperatures $\left(\mathrm{T}_{\mathrm{m}}<-26^{\circ} \mathrm{C}\right)$ has reduced from 1980's to the present but may not reduce much more in 2011-2040. Risk to shoots from fluctuating temperatures in winter and spring is likely to increase under the high warming scenario, more in the south-west than in the south-east. Risk to trees from cold days $\left(\mathrm{T}_{\mathrm{m}}<-15^{\circ} \mathrm{C}\right)$ with a concurrent thin snow cover is not predicted to increase. In the western inland of the country, below latitude $63^{\circ} \mathrm{N}$, and in the south-western coast areas the frost risk during flowering may increase, especially in the early flowering cultivars. In order to adapt to and gain from the climatic change, breeding and testing targets should be modified within five years and they should include reduced sensitivity to temperature fluctuation in winter, late flowering, and frost tolerance of flowers.

Key-words: Climate change, regional climate model, climatic index, winter injury, adaptation, acclimation 
Vol. 19 (2010): 144-159.

\section{Introduction}

In Finland, global climate change is expected to cause rise of seasonal mean temperatures in 2010 2039, relative to the mean values in 1961-1990, in winter by $1.2-5{ }^{\circ} \mathrm{C}$, in spring by $1.1-4.2^{\circ} \mathrm{C}$, in summer (June-August) by $0.6-1.6{ }^{\circ} \mathrm{C}$, and in fall (September-November) by $0.9-2.3{ }^{\circ} \mathrm{C}$ (Jylhä et al. 2004). The temperature change falls slightly outside the $95 \%$ interval of natural variation for all seasons. Changes in precipitation are in general positive, but mostly within the $95 \%$ interval of natural variation. In the past since 1960, mean daily temperatures in both spring (March-May) and winter (December-February) have risen by about 1 ${ }^{\circ} \mathrm{C}$; winter temperatures have risen to even a slightly higher extent, but their inter-annual variation has been much wider than that for spring temperatures (Tuomenvirta 2004). The climatic warming before the mid-century seems is so strong that it is meaningful to study its consequences on apple growing in Finland, despite that inherent climatic variability and model uncertainties are very large compared to the magnitude of warming.

In relation to the observed warming of the seasons in Europe and North America, phenological time series show advancement in the all-leafing, flowering and fruiting of cultivated and natural species, including apple (Malus domestica Borkh) (Wolfe et al. 2005, Menzel et al. 2006, Eccel et al. 2009).

Austin and Hall (2001) assessed the impact of climatic warming on future apple production in the mild maritime climate of New Zealand. They concluded that the warming will have no discernible effect on growth and development during the next 25 years and only very limited effects before 2050. Eccel et al. (2009) studied risk of frost during flowering over the next 50 years by using statistically downscaled climate data and a thermal model calibrated to two sites at the alpine region of Trentino in Italy. They concluded that the risk of frost is more likely to reduce than increase.

As regards the cool climate in eastern Canada, the impact on apple production has been found more significant. Rochette et al. (2004) assessed the risks for apple production during fall, winter and spring by computing semi-empirical agroclimatic indices, using climatic data from a General Circulation Model with a spatial resolution of $3.75^{\circ} \times 3.75^{\circ}$. The date of the first fall frost, averaged across eastern Canada, is expected to be delayed by 10 days in 2010-2039 and by 16 days in 2040-2069, in comparison to 1961-1990, and correspondingly, the last spring frost $\left(\leq-2{ }^{\circ} \mathrm{C}\right)$ would be advanced by 6 days in 2010-2039 and by 15 days in 2040-2069. The delay of the first fall frost was considered to enhance hardening in fall due to the prolongation of the period from the time point of induction of hardening by short daylength until the time of the frost. This conclusion, however, needs to be reconsidered after the finding by Heide and Prestrud (2005) that growth cessation and dormancy induction in apple are not influenced by photoperiod, but they are induced and controlled by low temperatures alone, which is contrary to the results by Howell and Weiser (1970a). The advance of the last spring frost, in connection with faster accumulation of growing degree days with the base temperature $5{ }^{\circ} \mathrm{C}$ (DD5), was predicted to reduce the frost risk to flower buds in the Continental North, to have no effect in the Maritimes and Ottawa Valley, and to increase the risk in the milder-climate southern Ontario.

An assessment by Winkler et al. (2002) in the Great Lakes region of the USA and Canada for 2025 to 2034 suggests that fruit-growing areas will experience a moderate prolongation of growing season, an increase in seasonal temperature accumulation, and a decrease in the frequency of freezing temperatures. They concluded that the risk of bud injury caused by fluctuating temperatures would increase in mild-climate southern Ontario, based on the accumulating temperature from the first frost in fall to the last frost in spring.

Our objective is to predict for Finland changes in suitability of apple cultivar types from the past decades to 2010-2040 and to assess what is needed to adapt to and possibly gain from the change. This study is limited to the first part of the 21 st century because projecting the changes in the apple growing beyond the mid-century would not be very meaningful at this stage. Firstly, by the mid-cen- 
Kaukoranta, T. et al. Climatic potential and risks for apple growing

tury, local fruit growing is likely to be affected at least as much by global economic and technological developments as by the climatic change. Secondly, the climate projections for Finland (Jylhä et al. 2004), based on the greenhouse gas emissions published in the Special Report on Emission Scenarios (SRES) by the Intergovernmental Panel on Climate Change (IPCC) (Nakicenovic et al. 2000), do not differ greatly before the year 2050, but thereafter the different emission scenarios result in widely varying estimates of climatic warming, which reduces the practical value of the predictions concerning biological impacts. The $\mathrm{CO}_{2}$ concentrations which are expected to be reached after 2050 (IPCC 2007) may also modify cold tolerance in winter and spring (Repo et al. 1996, Wayne et al. 1998) and the onset of hardening in fall (Taylor et al. 2008).

There are two parts in the estimation: potential and risks. The potential of an irrigated crop under cool climate is limited by warmness and length of growing seasons, described commonly by temperature accumulation over the season. The risks are caused by inadequate vegetative maturing due to cool summer (Tumanov et al. 1972, Lindén 2001), extreme coldness in winter (Quamme et al. 1976, Lindén et al. 1996, Caprio and Quamme 1999), fluctuating temperatures after dehardening late in winter and spring (Howell and Weiser 1970b, Ketchie and Beeman 1973, Coleman 1992, Caprio and Quamme 1999), and frost during flowering. The temporal patterns of weather leading to winter injury are rather well described in qualitative terms, but attempts to detect the causes by statistical analyses have been complicated by the fact that, in addition to large-scale climatic factors, the vulnerability of orchards to winter injuries is affected by the rootstock and cultivar resistance to cold, the age of trees, and the modification of local climate through the elevation and slope of the orchard, soil type, wind protection, and water bodies. This is well known in practice and established by surveys in Finland (Säkö and Pessala 1967) and in Quebec, Canada (Khanizadeh 2007).

\section{Methods}

\section{Climate data and production of maps}

Transient daily data on mean temperature $\left(\mathrm{T}_{\mathrm{m}}\right)$, minimum temperature $\left(T_{n}\right)$ and snow water equivalent in Finland during 1971-2040 were extracted from the European climate data for 1961-2100 with a spatial resolution of $0.44^{\circ}$ on the rotated coordinate system simulated by the regional atmospheric climate model RCA3 at the Rossby Centre, Sweden (Kjellström et al. 2005). The data were based on SRES A2 (Nakicenovic et al. 2000) and a global climate model (GCM) simulation by ECHAM4/ OPYC3 (Roeckner et al. 1999). It should be pointed out that also the past regional climate data were simulated, not measured. The climate data received from the Rossby Centre were processed with SAS software (SAS Institute Inc., Cary, NC, USA). The maps showing the gridded results under the geodesic coordinate system were drawn up by Mr. H. Ojanen using MapInfo software. The region of Åland Islands, west of south-western continental Finland, was not included in the data despite its being a locally important apple growing area, because the grid point of RCA3 covering the Alland Islands constitutes mainly of sea surface.

Point data on $T_{m}$ and $T_{n}$ in 1971-2000 from 14 weather stations operated by the Finnish Meteorological Institute (Table 1) were used for estimating the risk of fluctuating temperatures in winter and spring. The lowest and highest seasonal changes of mean temperature by 2010-2039 (SRES A2), given by Jylhä et al. (2004), were interpolated linearly with respect to day of year and year since 1961-1990 in order to obtain daily changes over the years 2011-2040. By adding the daily changes to the daily $T_{m}$ and $T_{n}$ values at the height of $2 \mathrm{~m}$ from the period 1971-2000 we obtained data sets for 2011-2040 with the same daily temperature range (DTR) as in 1971-2000, but with the mean and minimum values rising over the years. 
Vol. 19 (2010): 144-159.

Table 1. Weather stations for point data, location and altitude from sea level in metres. Mean annual number of frost days during flowering of cv. Samo during 1971-2000 and 2011-2040. Low and high scenario represent the lowest and highest seasonal temperature scenarios of temperature change given by Jylhä et al. (2004).

\begin{tabular}{|c|c|c|c|c|c|c|c|}
\hline $\mathrm{LPNN}^{1}$ & $\mathrm{WMO}^{2}$ & Station name & Location & Altitude & $\begin{array}{l}\text { Frost days } \\
1971-2000\end{array}$ & $\begin{array}{c}\text { Frost days } \\
2011-40 \\
\text { Low scenario }\end{array}$ & $\begin{array}{c}\text { Frost days } \\
2011-40 \\
\text { High scenario }\end{array}$ \\
\hline 0103 & 2828 & Piikkiö & $60^{\circ} 23^{\prime} \mathrm{N} 22^{\circ} 33^{\prime} \mathrm{E}$ & 6 & 0.7 & 0.7 & 0.3 \\
\hline 1104 & 2762 & Kokemäki & $61^{\circ} 16^{\prime} \mathrm{N} 22^{\circ} 15^{\prime} \mathrm{E}$ & 37 & 0.0 & 0.0 & 0.0 \\
\hline 1201 & 2963 & Jokioinen & $60^{\circ} 49^{\prime} \mathrm{N} 23^{\circ} 30^{\prime} \mathrm{E}$ & 104 & 0.7 & 1.0 & 0.0 \\
\hline 1302 & 2829 & Hyvinkää & $60^{\circ} 36^{\prime} \mathrm{N} 24^{\circ} 48^{\prime} \mathrm{E}$ & 86 & 0.3 & 0.7 & 0.0 \\
\hline 1306 & 5274 & Pälkäne & $61^{\circ} 20^{\prime} \mathrm{N} 24^{\circ} 12^{\prime} \mathrm{E}$ & 103 & 0.0 & 0.0 & 0.0 \\
\hline 1701 & 2958 & Lappeenranta & $61^{\circ} 03^{\prime} \mathrm{N} 28^{\circ} 09^{\prime} \mathrm{E}$ & 106 & 0.0 & 0.0 & 0.0 \\
\hline 2401 & 2935 & Jyväskylä & $62^{\circ} 24^{\prime} \mathrm{N} 25^{\circ} 41^{\prime} \mathrm{E}$ & 139 & 1.0 & 0.7 & 1.0 \\
\hline 2602 & 2947 & Mikkeli & $61^{\circ} 41^{\prime} \mathrm{N} 27^{\circ} 12^{\prime} \mathrm{E}$ & 101 & 0.0 & 0.0 & 0.3 \\
\hline 3101 & 2833 & Ylistaro & $62^{\circ} 56^{\prime} \mathrm{N} 22^{\circ} 29^{\prime} \mathrm{E}$ & 26 & 2.3 & 0.0 & 0.3 \\
\hline 3301 & 2924 & Ähtäri & $62^{\circ} 32^{\prime} \mathrm{N} 24^{\circ} 13^{\prime} \mathrm{E}$ & 157 & 3.7 & 1.4 & 0.7 \\
\hline 3603 & 2788 & Maaninka & $63^{\circ} 09^{\prime} \mathrm{N} 27^{\circ} 19^{\prime} \mathrm{E}$ & 90 & 0.3 & 0.3 & 0.0 \\
\hline 3801 & 2929 & Joensuu & $62^{\circ} 40^{\prime} \mathrm{N} 29^{\circ} 37^{\prime} \mathrm{E}$ & 121 & 0.3 & 0.3 & 0.7 \\
\hline 4601 & 2897 & Kajaani & $64^{\circ} 17^{\prime} \mathrm{N} 27^{\circ} 41^{\prime} \mathrm{E}$ & 147 & 2.0 & 1.3 & 1.3 \\
\hline 5401 & 2875 & Oulu & $64^{\circ} 56^{\prime} \mathrm{N} 25^{\circ} 21^{\prime} \mathrm{E}$ & 14 & 0.0 & 0.0 & 0.0 \\
\hline
\end{tabular}

${ }^{1}$ LPNN National identification number

${ }^{2}$ WMO World meteorological organisation identification code

\section{Agro-climatic indices}

Frost injury during flowering. The starting point for estimating the risk of frost during flowering is to predict the time of the flowering. In mild climates, the prediction is based on chilling temperatures in winter, which release the dormancy of buds, and on spring temperatures that drive the development of the buds (Richardson et al. 1974, Atkins and Morgan 1990, Legave et al. 2008). In climates with cold winters, the chilling requirement is met during winter under the present climatic conditions (Kronenberg 1979), and will easily be met in winter under the conditions expected by the mid-century in Finland (Jylhä et al. 2004). In the present climate, the timing of flowering in Quebec, Canada (Rochette et al. 2004) and in Finland (Ylämäki, unpublished) is predicted by a linear degree-day model without considering the chilling requirement.
The frost risk was first assessed using the point data in 1971-2000 and lowest and highest scenarios (Jylhä et al. 2004) for the years 2010-2040. For the point data, daily minimum temperature below $-2{ }^{\circ} \mathrm{C}$ was set as the condition for frost during flowering. Under field conditions $-2{ }^{\circ} \mathrm{C}$ at two metre height is generally a threshold for frost damage. The flowering time was predicted by computing DD5 from the start of a year and using cultivar specific DD5 values for the start and end of flowering (Table 2), as observed at MTT Horticulture, Piikkiö (60²3' N, 22³3' E) (Ylämäki, unpublished). Under the semi-continental climate of Finland, the choice of base temperature above $0{ }^{\circ} \mathrm{C}$ affects very little the prediction as the temperatures rise quite rapidly in spring. The vulnerable period was set to start 20 DD5 before the start of flowering. Having 
Kaukoranta, T. et al. Climatic potential and risks for apple growing

estimated, from the point data, the number of frost days during flowering per decade, the $\mathrm{T}_{\mathrm{n}}$ threshold for the RCA3 data was adjusted to give a roughly equal number of frost days as that found by means of the point data. Using RCA3 data annual numbers of frost days during flowering and from these means for periods 1981-2010 and 2011-2040 were computed.

Harvesting of fruits. The date of fruit maturing of the cultivars was computed from the RCA3 data based on DD5 accumulated from the start of the year. The number of years in a decade when fruits were predicted to mature successfully was computed to obtain the frequency of fruit maturing by decade. The frequency was scaled to the range from 0 to 1 . Temperature accumulation requirements for each cultivar (Table 2) were derived from data collected from trials at MTT Horticulture, Piikkiö (Ylämäki and Tahvonen 1998). In these trials, it has been found that, during hot periods in late July and August when daily maximum temperatures are roughly above 25 ${ }^{\circ} \mathrm{C}$, the development of the fruits and trees actually slows down. To study the effect of this phenomenon, temperature accumulation was computed also in another way: after 500 DD5 in days when daily maximum temperature $\left(\mathrm{T}_{\mathrm{m}}\right)$ exceeded $20^{\circ} \mathrm{C}$, the daily accumulation was cut to a low value, which was arbitrarily set at 5 DD5.

Table 2. Degree-day (base temperature $5{ }^{\circ} \mathrm{C}$ ) requirements for flowering (flowers open) and harvest maturity of apple cultivars.

\begin{tabular}{|c|c|c|c|c|}
\hline Group & Cultivar & $\begin{array}{l}\text { Flowering } \\
\text { start }\end{array}$ & $\begin{array}{l}\text { Flowering } \\
\text { end }\end{array}$ & $\begin{array}{l}\text { Fruit } \\
\text { maturing }\end{array}$ \\
\hline Summer & Pirja & 170 & 210 & 970 \\
\hline Summer & Petteri & 180 & 220 & 1120 \\
\hline Early fall & Samo & 165 & 205 & 1160 \\
\hline Late fall & Melba & 178 & 218 & 1190 \\
\hline Late fall & Sandra & 190 & 230 & 1195 \\
\hline Late fall & Pekka & 190 & 230 & 1230 \\
\hline Winter & Tobias & 195 & 235 & 1240 \\
\hline Winter & Lobo & 200 & 240 & 1300 \\
\hline Winter & Aroma & 200 & 240 & 1340 \\
\hline
\end{tabular}

Requirement of temperature accumulation for vegetative maturity. According to the experiments carried out at MTT Horticulture, Piikkiö, vegetative maturity of trees requires temperature accumulation that is approximately 100-150 DD5 higher than that needed by the harvesting of fruits (Tahvonen, unpublished). We used a rule that 100 DD5 on top of harvesting maturity, as given in Table 2, would provide vegetative maturity that will ensure stable yield year after year in the studied cultivars. The RCA3 data were used. The numbers of years in 1981-2010 and 2011-2040 when vegetative maturity of trees was predicted to be reached were computed to obtain the frequency of vegetative maturing in the respective periods. The frequency was scaled to the range from 0 to 1 .

\section{Extreme cold and temperature fluctuation in winter.} Shoots of apple cultivars grown in cool climate areas can tolerate momentarily very low temperatures, down to -30 to $-40{ }^{\circ} \mathrm{C}$ (Lindén et al. 1996, Quamme et al. 1976) when they are properly hardened. Yet, Caprio and Quamme (1999) concluded from a statistical analysis of apple production data in British Columbia, Canada, that low temperatures during November, December and February $\left(-7^{\circ} \mathrm{C}\right.$ to $-29^{\circ} \mathrm{C}$ ) were the main climatic factor limiting the apple production. Similarly, Lindén (2001) found that the variables indicating mid-winter severity, i.e., the monthly mean, minimum, and maximum temperatures from January to March, predicted well winter injuries in historical data in Finland. A precondition for the cold tolerance is that a growing season is warm enough for the termination of apical elongation and the subsequent hardening (Tumanov et al. 1972). There is evidence for Finland derived statistically by Lindén (2001) that low temperature accumulation during growing season has been associated with winter-kill years. In fall the hardening is initiated by low temperatures according to Heide and Prestrud (2005) but a rapid and permanent drop of temperatures from above the hardening level to a winter level will leave apple trees vulnerable to winter injury.

Fluctuating temperatures in winter cause bud and shoot damage in dehardened trees (Howell and Weiser 1970b, Ketchie and Beeman 1973). 
Vol. 19 (2010): 144-159.

The phenomenon emerged also in the surveys by Caprio and Quamme (1999) in British Columbia, Canada, and by Coleman (1992) in New Brunswick, Canada. Ketchie and Beeman (1973) showed that the temporal pattern of cold resistance is different from year to year making it difficult to find a single quantitative measure from experimental or survey data to predict the cold injury under variable climate.

(1) Days with $\mathrm{T}_{\mathrm{m}}$ below $-27{ }^{\circ} \mathrm{C}$ were considered to be extremely cold and potentially damaging to shoots or entire trees. The annual number of days with $T_{m}$ below this threshold in winter was computed from the RCA3 data. When $\mathrm{T}_{\mathrm{m}}$ is $-27^{\circ} \mathrm{C}$, $\mathrm{T}_{\mathrm{n}}$ is below $-30{ }^{\circ} \mathrm{C}$ which is near the lowest temperatures momentarily tolerated by shoots, -30 to $-40{ }^{\circ} \mathrm{C}$ (Lindén et al. 1996, Quamme et al. 1976). Temperature fluctuation in winter was studied with point data using the lowest and highest warming scenario (Jylhä et al. 2004) and RCA3 data. The fluctuation was expressed as temperature accumulation in DD5 units from the start of year until the occurrence of the last daily minimum temperature $\left(T_{n}\right)$ below the set threshold.

(2) For the point data, the $T_{n}$ threshold was -15 ${ }^{\circ} \mathrm{C}$. Only $\mathrm{T}_{\mathrm{n}}$ below this threshold were considered damaging to shoots during the periods when $T_{m}$ exceeds $5{ }^{\circ} \mathrm{C}$. The threshold represents local practical opinion and is in the range found by Ketchie and Beeman (1973). In their experiment bark from young trees showed increased electrolyte conductance at -10 to $-25{ }^{\circ} \mathrm{C}$ when $\mathrm{T}_{\mathrm{x}}$ was above $5^{\circ} \mathrm{C}$ in February in Washington, USA.

(3) Using the RCA3 data, 18 different $T_{n}$ threshold values were tried by stepping the $\mathrm{T}_{\mathrm{n}}$ threshold from $-15^{\circ} \mathrm{N}$ to $2^{\circ} \mathrm{C}$ by $1{ }^{\circ} \mathrm{C}$ increments.

Low temperatures with a concurrent thin snow cover. To establish the frequency of conditions injuring roots and rootstock, the number of days in winter with $\mathrm{T}_{\mathrm{m}}$ below $-15^{\circ} \mathrm{C}$ and snow water equivalent below $15 \mathrm{~mm}$ were computed from the RCA3 data. Water equivalent above $15 \mathrm{~mm}$ was considered to significantly slow down fall of temperature in soil. There is no published data on the exact tolerance of apple roots and rootstock to cumulative cold. Yet, periods with $\mathrm{T}_{\mathrm{m}}$ under $-15^{\circ} \mathrm{C}$ for several days are not common below the latitude $65^{\circ} \mathrm{N}$ in Finland under the current climate but when such cold spells have occurred, dying of entire trees has been observed (Tahvonen, unpublished). Differences in cold tolerance between the cultivars were not taken into account.

\section{Results}

Due to lack of space graphs and tables for all cultivar and index combinations are not presented. For combinations not shown in graphs the results are described in the text.

\section{Frost injury during flowering}

Result for early fall type cv. Samo (Table 1) shows the trends found for all cultivars using the point data. Generally the risk is expected to stay at current level or decrease. The risk is high under present climatic conditions inland in western Finland (locations Ylistaro, Ähtäri) and in the north-west (Kajaani), but reduces both under the lowest and highest seasonal temperature scenarios. The risk will remain lowest at lake areas (Lappeenranta, Mikkeli in the south-east, Pälkäne in the south), by the sea in the north (Oulu) and in the west (Kokemäki). Note that all cultivars do not mature at all sites (see results in chapter 2 below).

Based on RCA3 data, the start of flowering will advance from 1971-2000 to 2011-2040 by 6 to 10 days in the south-west, and 5 to 7 days in other areas. Using RCA3 data, the threshold values $4{ }^{\circ} \mathrm{C}$ and $5{ }^{\circ} \mathrm{C}$ yielded frost risk of the same magnitude as the $-2{ }^{\circ} \mathrm{C}$ threshold for the point data in central and western Finland. Using the threshold of $5^{\circ} \mathrm{C}$ with the RCA3 data, the risk increased in 20112040 in the southern inland part of the country for all cultivars, but especially for the early flowering cultivars Pirja, Samo, Petteri, and Melba, while it decreased in the west and remained low in the east. Result for cv. Pirja is shown in Figure 1. 
Kaukoranta, T. et al. Climatic potential and risks for apple growing

Fig. 1. Spatial distribution of mean number of potential frost days per year during flowering of cv. Pirja in 1981-2010 and 2011-2040. Legend mean number of potential frost days.
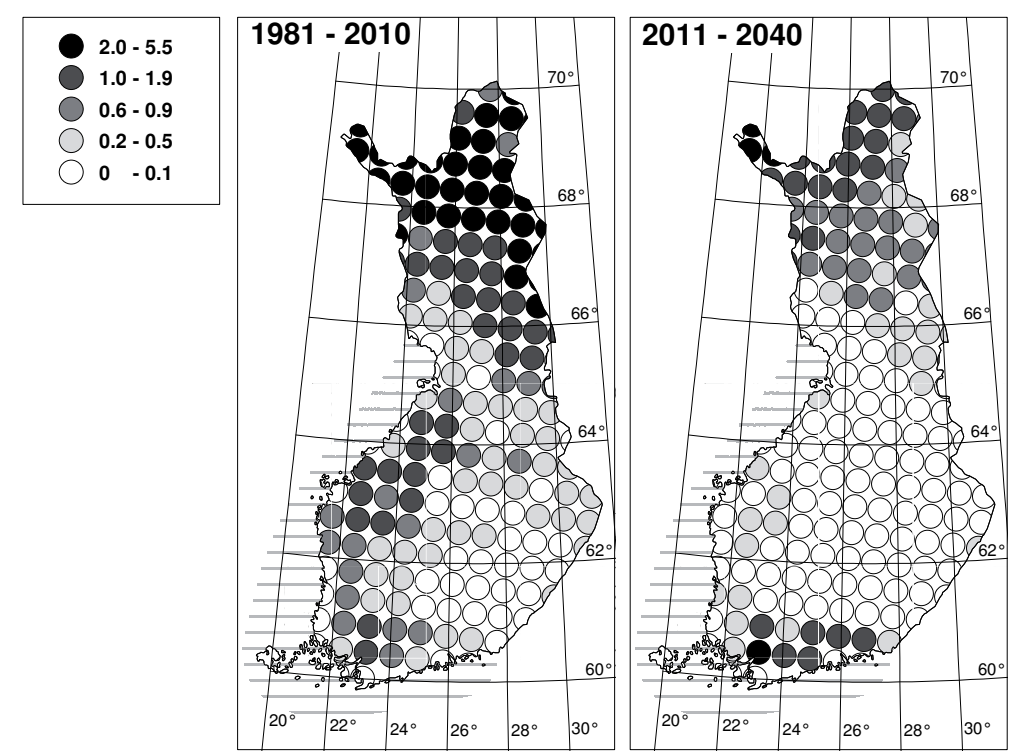

\section{Maturing of fruits}

From the 1970's to the present day, the areas of successful maturing of fruits have strongly expanded northwards. An example of this is the potential maturing area of cv. Melba shown in Figures 2. During the following three decades, the maturing areas are predicted to continue expanding, though not as rapidly as in the past and mainly over central and western Finland where apple is grown only in home gardens. The very early maturing cultivars (cv. Pirja) are predicted to produce fully matured crops every year up to the latitudes 65 to $66^{\circ} \mathrm{N}$ in $2021-2040$ (results not shown). Late maturing cvs Melba (Fig. 2), Sandra, Pekka and Tobias (results not shown) will mature every year up to the latitudes 61 to $62^{\circ} \mathrm{N}$ in the west and to the latitudes 62 to $63^{\circ} \mathrm{N}$ in the east, reflecting the effect of lake-richness in the east and hills in central and western Finland. Currently, the latest maturing, commercially grown cultivar on the continental Finland, Lobo, has produced mature fruits since 1991 only along the Baltic Sea in southern Finland and along the shores of large lakes in south-eastern Finland. In 2011-2040, Lobo is expected to mature in the whole southern part of the country up to the latitudes $61^{\circ} \mathrm{N}$ in the west and $62^{\circ} \mathrm{N}$ in the south-eastern lake area (results not shown). The cultivar Aroma, currently recommended only for the south-western archipelago, is expected to mature along the southern coast and with high probability also on the southern part of the eastern lake area (Fig. 3).

When studying the possible effect of hot days on fruit development by limiting the accumulation of temperature to $5 \mathrm{DD} 5$ in a situation where the $\mathrm{T}_{\mathrm{m}}$ exceeded $20^{\circ} \mathrm{C}$, it was found that the limitation did not have any significant effect on the spatial pattern of success of maturation for the majority of cultivars; only the maturing areas of the very late maturing cultivars Lobo and Aroma were locally reduced in southern inland Finland (results not shown). 


\section{AGRICULTURAL AND FOOD SCIENCE}

Vol. 19 (2010): 144-159.
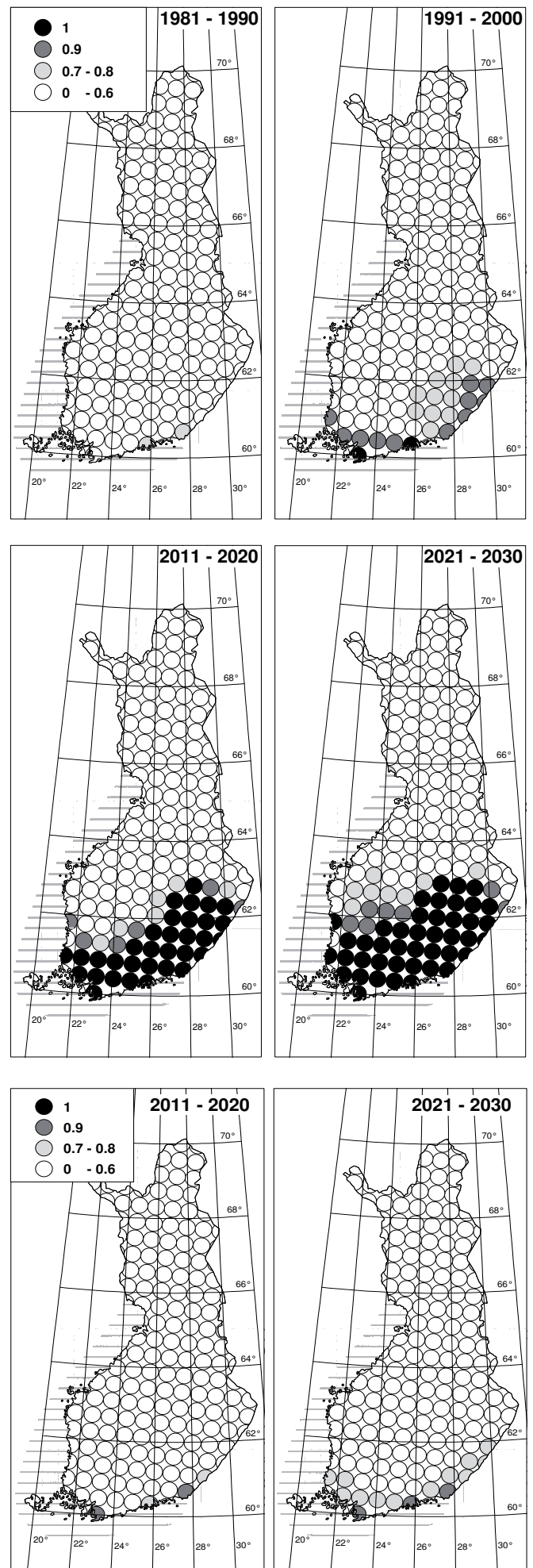
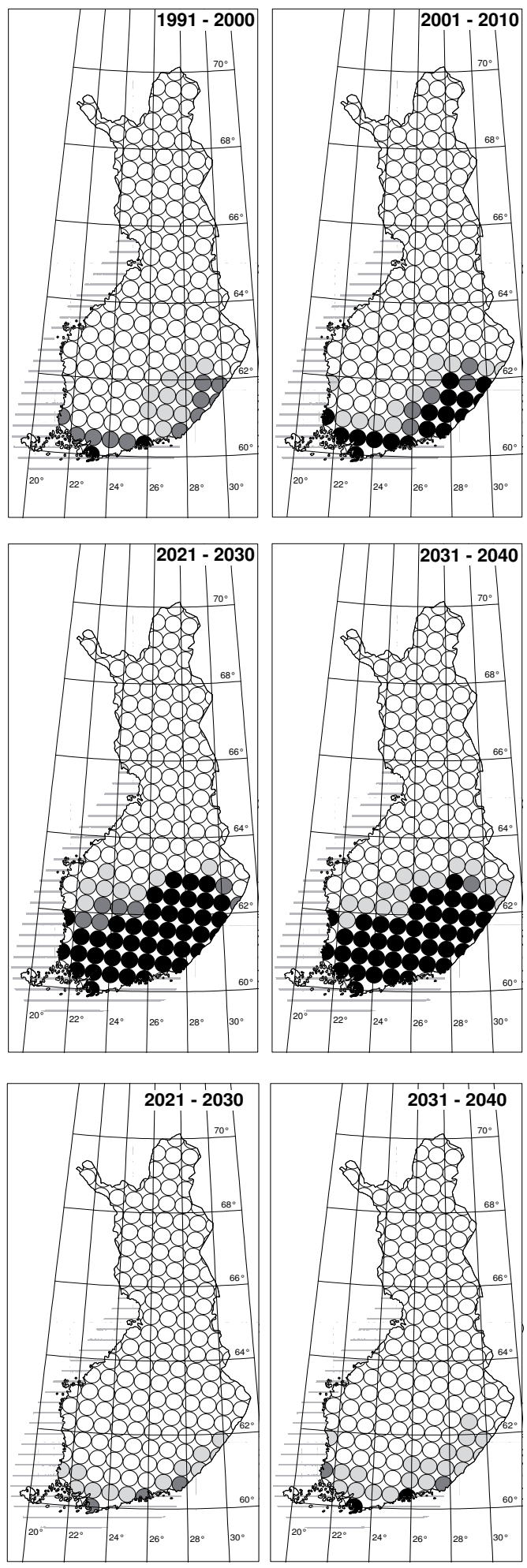

Fig. 2. Change of spatial distribution of frequency of successful fruit maturing for cv. Melba by decade on scale $0-1$. Legend frequency.
Fig. 3. Change of spatial distribution of frequency of successful fruit maturing for cv. Aroma by decade on scale $0-1$. Legend frequency. 
Kaukoranta, T. et al. Climatic potential and risks for apple growing

\section{Requirement of temperature accumulation for vegetative maturity}

The areas where temperature accumulation during growing season is sufficient for successful vegetative maturity are expected to extend 200 to $300 \mathrm{~km}$ northwards during the period 2011-2040 in comparison to the period 1981-2010. The very early maturing cultivars (cv. Pirja) are expected to get well ready for winter every year in 2011-2040 up to the latitudes 64 to $65^{\circ} \mathrm{N}$ and in eight years out of ten up to the latitudes 65 to $66^{\circ} \mathrm{N}$ (Fig. 4). The slightly later summer cultivars (cv. Petteri, results not shown) and the fall cultivars Samo (Fig. 5), Melba and Sandra (results not shown), will get ready for the winter every year in the whole southern and central Finland. The late fall cv. Pekka (Fig. 6) and early winter cv. Tobias (results not shown) will terminate successfully their development in the
Fig. 4. Change of spatial distribution of frequency of reaching vegetative maturity for $\mathrm{cv}$. Pirja in 1981-2010 and 2011-2040 on scale $0-1$. Legend frequency

Fig. 5. Change of spatial distribution of frequency of reaching of vegetative maturity for cv. Samo in 1981-2010 and 20112040 on scale $0-1$. Legend frequency.
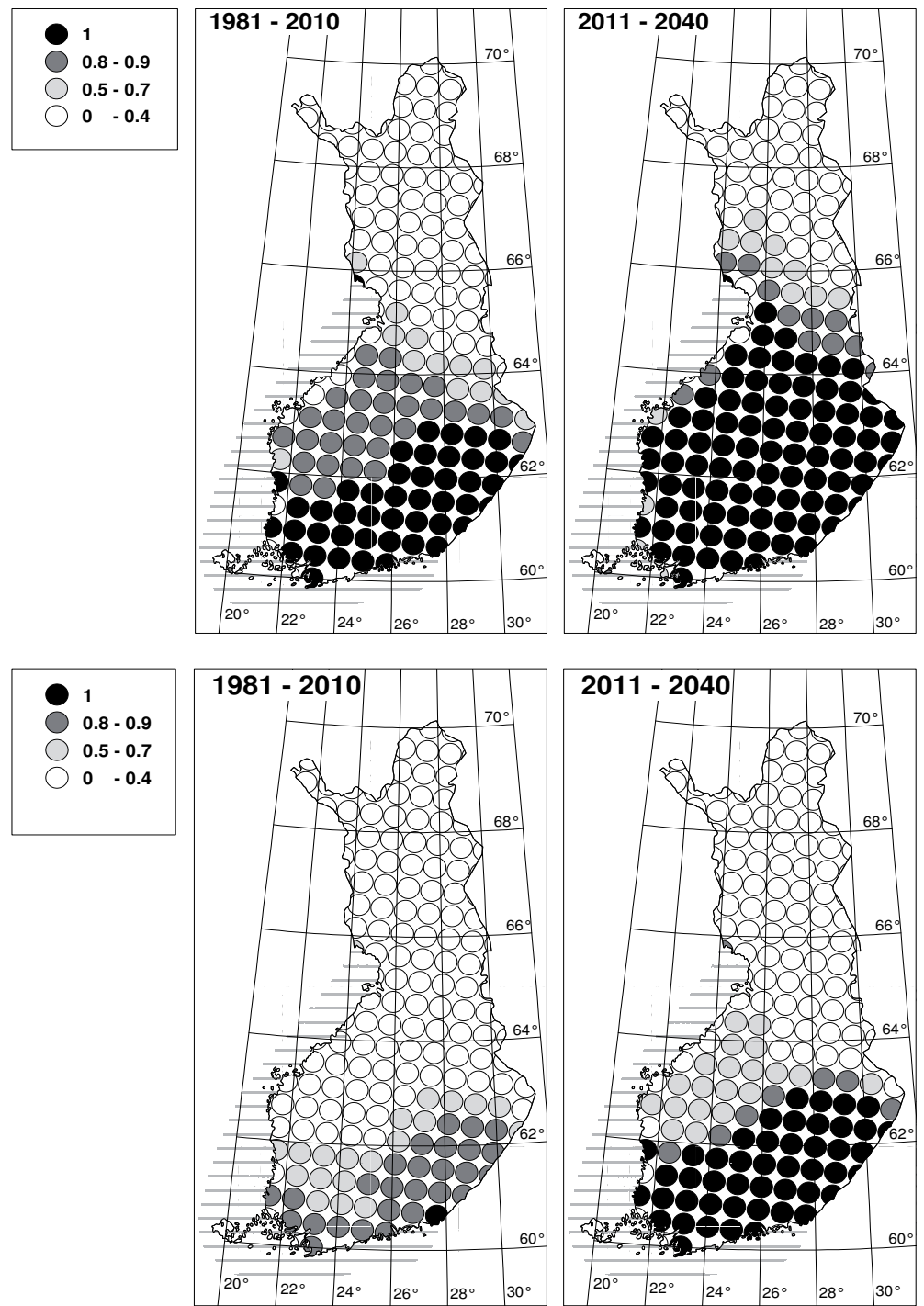
Vol. 19 (2010): 144-159.

southern part of the country and in the south-eastern lake area. The latest maturing cultivars Lobo (Fig. 7) and Aroma (results not shown) were not able to prepare themselves for winter in most years in the continental Finland during the period 1981-2010.
During the next 30 -year period they would be safe choices for orchards and home gardens only in the south-western coastal area and along lake shores in the south-east.
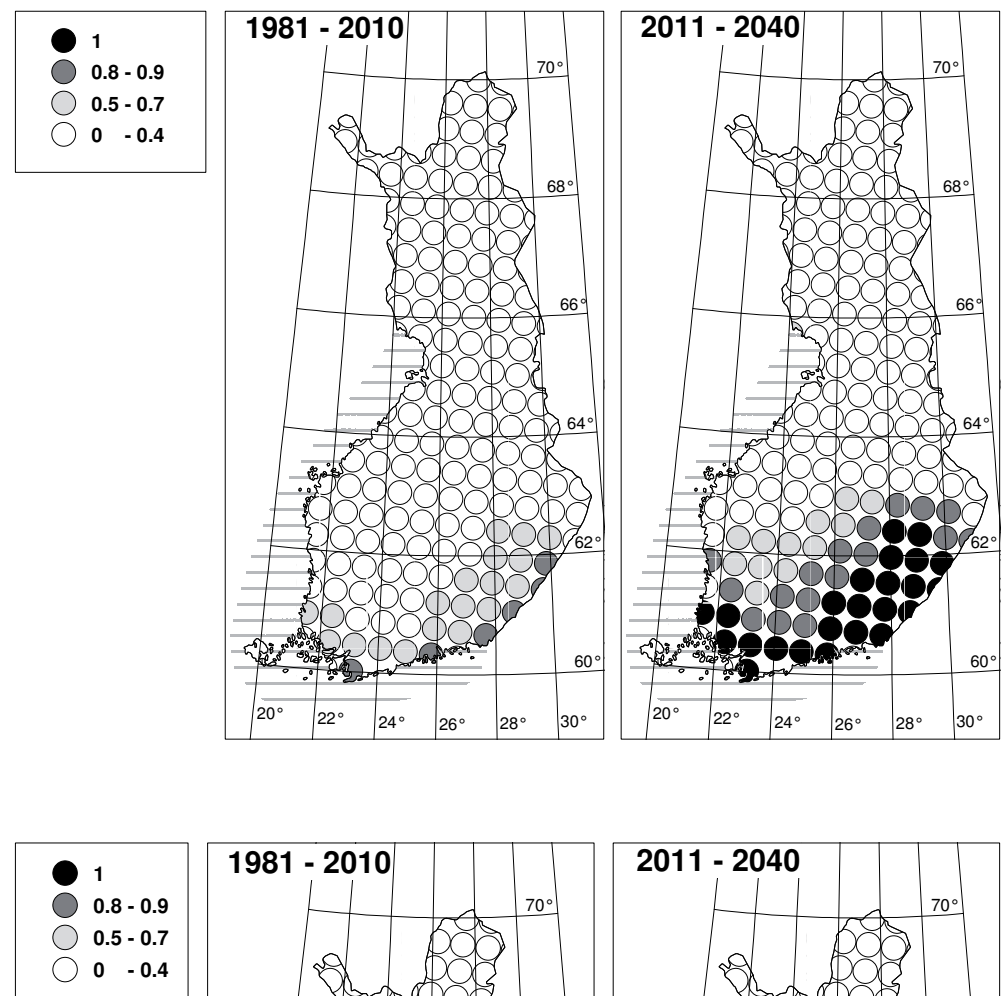

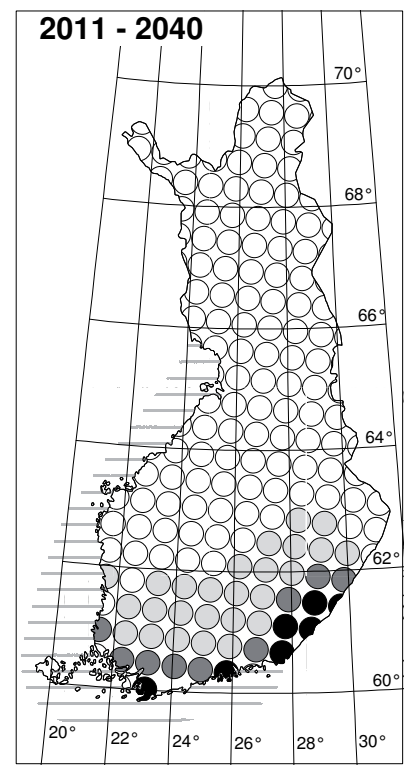

Fig. 6. Change of spatial distribution of frequency of reaching vegetative maturity for $\mathrm{cv}$. Pekka in 1981-2010 and 20112040 on scale $0-1$. Legend frequency.
Fig. 7. Change of spatial distribution of frequency of reaching vegetative maturity for cv. Lobo in 1981-2010 and 2011-2040 on scale $0-1$. Legend frequency. 
Kaukoranta, T. et al. Climatic potential and risks for apple growing

\section{Extreme cold and temperature fluctuation in winter}

(1) The frequency of very cold days $\left(T_{m}\right.$ below $-27^{\circ} \mathrm{C}$ ) has diminished from the 1970 s to the 1990 s and into the present decade. RCA3 does not predict further reduction of very cold days over the next three decades south of latitudes 65 to $66^{\circ} \mathrm{N}$ where the coldness is an issue for apple growing in home gardens (results not shown). Above these latitudes the cultivars included in the study cannot be grown.

(2) Using the point data, it was found that with the lowest warming scenario, from the start of the year to the last day when $\mathrm{T}_{\mathrm{n}}$ was below $-15^{\circ} \mathrm{C}$, temperature accumulation did not change appreciably at any station point (Table 3 ). With the highest scenario, the accumulation increased at all sta-

Table 3. Degree-day (DD5) (base temperature $5{ }^{\circ} \mathrm{C}$ ) accumulation from January 1 until the last day when daily minimum temperature is $-15^{\circ} \mathrm{C}$. Low and high scenario represent the lowest and highest seasonal temperature scenarios of temperature change given by Jylhä et al. (2004). Location of the stations is given in table 1 .

\begin{tabular}{lccc}
\hline Station name & $1971-2000$ & $\begin{array}{c}2011-40 \\
\text { Low } \\
\text { scenario }\end{array}$ & $\begin{array}{c}\text { 2011-40 } \\
\text { High } \\
\text { scenario }\end{array}$ \\
\hline Piikkiö & 0.2 & 0.7 & 15.1 \\
Kokemäki & 0.1 & 0.9 & 17.3 \\
Jokioinen & 0.0 & 0.5 & 13.8 \\
Hyvinkää & 0.0 & 0.3 & 14.8 \\
Pälkäne & 0.0 & 0.1 & 8.8 \\
Lappeenranta & 1.4 & 1.8 & 8.8 \\
Jyväskylä & 0.0 & 0.2 & 10.3 \\
Mikkeli & 0.0 & 0.1 & 6.4 \\
Ylistaro & 0.1 & 0.4 & 13.9 \\
Ähtäri & 0.0 & 0.3 & 12.1 \\
Maaninka & 0.0 & 0.3 & 10.9 \\
Joensuu & 0.0 & 0.2 & 6.6 \\
Kajaani & 0.1 & 0.5 & 10.8 \\
Oulu & 0.2 & 0.7 & 12.0 \\
\hline
\end{tabular}

tions, most in the south-west (Piikkiö, Jokioinen, Kokemäki, Hyvinkää) being 14-17 DD5 and least in the east (Joensuu) and south-east (Lappeenranta, Mikkeli) in 2011-2040. In terms of days with $\mathrm{T}_{\mathrm{m}}$ above $5{ }^{\circ} \mathrm{C}$ before the last $\mathrm{T}_{\mathrm{n}}$ was $-15^{\circ} \mathrm{C}$, the change under the highest scenario was from near zero in 1971-2000 to 5-9 days in 2011-2040.

(3) With the RCA3 data, the $T_{n}$ threshold had to be raised to $2{ }^{\circ} \mathrm{C}$ before $10-20$ DD5 was accumulated in any part of country (results not shown), which means that RCA3 data cannot be used for assessing fluctuation late in winter and spring.

\section{Low temperatures with a concurrent thin snow cover}

According to the RCA3 data, the risk conditions with combined low temperature $\left(\mathrm{T}_{\mathrm{m}}\right.$ below $\left.-15^{\circ} \mathrm{C}\right)$ and thin snow cover (snow water equivalent less than $15 \mathrm{~mm}$ ) would be infrequent during 2011-2040 within the entire area where apple can be grown commercially and in home gardens. The risk varies from decade to decade without any apparent trend (results not shown).

\section{Discussion}

The transient gridded data of RCA3 facilitate the study of the impact of daily and annual variation on the spatial and temporal changes in the adaptation of apple cultivars. Kjellström et al. (2005) reported that, in northern Europe, the inter-annual variation simulated by RCA3 is close to the variation found in the ERA40 reanalysis data (Uppala et al. 2005). RCA3 simulates $T_{m}$ within $\pm 1{ }^{\circ} \mathrm{C}$ of ERA 40 values, except in fall and winter in the north-eastern part of their model domain over Russia. Thus, if the performance of RCA3 for the past climate in northern Europe is considered to be a sufficient proof for its performance for the next three decades, $T_{m}$ values from RCA3 SRES A2 are satisfactorily reliable for our study. 
Vol. 19 (2010): 144-159.

However, there are some limitations in the data which are shared by other regional climate models (RCM). According to Kjellström et al. (2005), in the areas covering the central and southern parts of Finland, DTR of RCA3 was in spring and summer about $2{ }^{\circ} \mathrm{C}$ smaller than in the ERA40 data (Uppala et al. 2005). RCA3 overestimated $T_{n}$ throughout a year in the area covering Finland: in southern Finland by 1 to $2{ }^{\circ} \mathrm{C}$, and in northern Finland even more in winter and spring. Switching to another RCM or using averaged data from several RCMs would not offer a much better starting point. According to Kjellström et al. (2007) the ten RCMs they investigated, underestimated cold extremes in winter and warm extremes in summer by several degrees Celsius in northern Europe, including Finland. They assume that some fraction of the warm bias may be due to an effect of the boundary conditions originating from driving GCMs and not due to the RCMs.

Examination of the RCA3 data shows that it reflects the effects of the Baltic Sea coasts, large inland water bodies, such as the lake area in southeastern Finland, and large area altitude differences. Yet, because of the grid cell size it cannot detect the effects of smaller lakes and hill chains which are known to modify significantly local climate, affecting the suitability of any site for perennial crops. Furthermore, orchards are generally established in sites which are less prone to low night and winter temperatures than the entire RCA3 grid cell which contains the orchard sites. The limited spatial resolution of RCA3 and the bias in $\mathrm{T}_{\mathrm{n}}$ mean that the potentials and risks mapped in this study need to be seen only as broadly describing the spatial and temporal trends and not as accurate predictions for any individual site in the mapping area. The data from RCA3 are best suitable for predicting the development of apple in summer and the risk of cold injuries caused by long lasting cold spells in winter. Short cold spikes in winter and during flowering are not well detected.

The frost risk during flowering in 2011-2040 in comparison to 1981-2010, based on RCA3 data, is expected remain at current level in most of the country, reduce in the west, but increase for all cultivars in the southern part of the country. The early flowering cultivars will be particularly vulnerable. The geographic differences arise naturally from the gradient of continentality of climate which increases from the south-west to the north-east of the Finland, and from the effect of lakes in the southeast. A point to mention for comparison in pest and yield potential studies is that the flowering is predicted to advance 5 to 10 days from 1971-2000 to 2011-2040.

The potential growing area where the temperature accumulation during growing season is sufficient for successful vegetative maturity and, consequently, for successful hardening, is expected to extend 200 to $300 \mathrm{~km}$ northwards during the period 2011-2040 in comparison to 1981-2010. Much of the expansion of the potential has already taken place since the 1970 's, which can be partially a result of temporary climatic variation or a result of the global warming trend. If the coming years show that the warming experienced this far is permanent, the expansion of the potential growing area of the cultivars may no longer proceed as rapidly. Rather, the effect of the climatic warming trend would be the stabilization of the expansion experienced since the 1990's without any occasional retreat southwards, even despite of climatic variation in the coming decades.

The very early cultivars, for example, cv. Pirja, are expected to be able to terminate their vegetative development every year in 2011-2040 up to the latitudes 64 to $65^{\circ} \mathrm{N}$ and in eight years out of ten up to the latitudes 65 to $66^{\circ} \mathrm{N}$. The slightly later summer cultivars, cv. Petteri, and the fall types, cvs Samo, Melba and Sandra, will get ready for the winter every year in the whole southern and central Finland. The late fall cultivars, cv. Pekka, and the early winter types, cv. Tobias, will reach vegetative maturity in the southern part of the country and in the south-eastern lake area. In 1981-2010, the latest maturing cultivars Lobo and Aroma could not fully prepare themselves for winter in most years in the continental Finland. During the next 30-year period they are expected to terminate successfully their development along the south-western Baltic Sea coast and along lake shores in the south-east Finland. 


\section{AGRICULTURAL AND FOOD SCIENCE}

\section{Kaukoranta, T. et al. Climatic potential and risks for apple growing}

The very early maturing cultivars are predicted to produce mature fruits up to the latitudes 65 to $66^{\circ} \mathrm{N}$ in $2011-2040$. Correspondingly, the late maturing cultivars, Melba, Sandra, Pekka, and Tobias, will mature up to the latitudes 62 to $64^{\circ} \mathrm{N}$. In the decade 2031-2040, which in the simulations is assumed to be slightly cooler than the preceding decade 2021-2030, the maturing area extends further north in eastern Finland than in western parts of the country, reflecting the warming effect of large lakes in the east and the cooling effect of the hills in central and western inland Finland. Lobo, the latest maturing, commercially grown cultivar in the continental Finland, has since 1991 produced mature yield only on the Baltic Sea coast in southwestern Finland and along the shores of the large lakes in south-eastern Finland. In 2011-2040, Lobo is expected to mature in the whole southern part of the country. The cultivar Aroma, currently recommended only for the south-western coast and the archipelago, is expected to mature in western continental Finland up to the latitude $61^{\circ} \mathrm{N}$ and in the south-eastern lake area up to the latitude $62^{\circ} \mathrm{N}$. Even cultivars which require 1400 DD5 for fruit maturing may produce stable yield along the southwestern coast and in the south-eastern lake area. With longer and warmer seasons, the prediction of fruit maturity of the currently latest maturing cultivars, Lobo and Aroma, would need to corrected for nonlinearity of the temperature response inland in southern Finland. The nonlinearity has been shown to be significant by Stanley et al. (2000), though in conditions with much longer growing seasons of New Zealand.

The frequency of extremely cold days has been observed to diminish from 1970s to the present (Tuomenvirta et al. 2000), which is caught by RCA3. According to RCA3 (Kjellström et al. 2005), the frequency is not expected to diminish further in the next three decades south of northern border of apple growing, latitudes 65 to $66^{\circ} \mathrm{N}$. Yet, cold winter weather will not be uncommon in the eastern and northern part of the country. In the south-west and west, extreme coldness will be a lesser risk, but winter injuries may be caused by fluctuating temperatures after reduced dormancy late in winter and spring. Assuming similar distri- bution of temperatures in 2011-2040 as in 19712000 and the highest warming scenario (Jylhä et al. 2004), it is expected that apple trees will be in a clearly more vulnerable state in 2011-2040 when they meet the last very cold days $\left(\mathrm{T}_{\mathrm{n}}<-15^{\circ} \mathrm{C}\right)$. The change is larger in the west and south-west reflecting stronger expected warming of springs in the west (Jylhä et al. 2004). Under the lowest warming scenario, there would be no change in the risk of very cold days late in winter. It is also possible that the assumed variation of temperature in 2011-2040 is somewhat too large. In the last decades, DTR in winter and spring has reduced in Finland (Tuomenvirta et al. 2000) reflecting the global trend (Kaas and Frich 1995).

In the past, in winters when there has been little protective snow cover, low temperatures have been an occasional problem in central and western Finland. The RCA3 data suggest that the frequency of days with temperature below $-15^{\circ} \mathrm{C}$ when there is little protective snow cover should not increase. However, the reliability of this prediction may be low as the thickness of snow cover and its insulating value are rather hard to predict with a climate model.

High soil moisture and high temperatures in September as well as drought in August are known to interfere with the hardening of apple trees in the present climate (Lindén 2001). Yet, it is not clear whether it has been the soil moisture itself or the rather high temperatures at the time of drought that have affected trees in the past because it has been observed that high temperatures in July and August delay the development of irrigated trees and their fruits in Finland (Ylämäki, unpublished). RCA3 predicts only small changes in temperature and precipitation in October and November in Finland. Earlier, using data from several models, Jylhä et al. (2004) predicted a rise of 0.9 to $2.9^{\circ} \mathrm{C}$ in fall temperatures during 2010-2039 from/in comparison to 1961-1990, and a slight increase of precipitation, 0 to $15 \%$, over entire Finland. Change of average fall temperature is probably beneficial for the hardening of the late cultivars. A potential problem for the hardening lies in a possible sudden drop of temperature after a warm fall which will not disappear during 2010-2039 because the alternation of mari- 
Vol. 19 (2010): 144-159.

time western and continental north-eastern flows will stay. Perhaps, a more important change in fall is the rising importance of root and shoot canker caused by Phytophtora de Bary and Pythium Pringsheim species, and Nectria galligena Bres. which benefit from mild and wet conditions. There are already indications from the experimental orchard in Piikkiö that warm falls have aggravated injury from these pathogens.

In an ideal model, all the phases of development over a growing season and overwintering should condition the later phases, as they are qualitatively known to do (Howell and Weiser 1970b, Tumanov 1972, Ketchie and Beeman 1973, Coleman 1992, Caprio and Quamme 1999, Lindén 2001, Heide and Prestrud 2005, Khanizadeh 2007). This approach has long been pursued with forest trees but the models are still far from ready to predict the effect of climatic change (Hänninen 2006, Linkosalo et al. 2006, Hänninen and Kramer 2007). With fruit trees this approach would require more quantitative, cultivar specific information on response of trees to environment in winter, and a higher spatial resolution of projected climate data and better prediction ability of the daily and monthly ranges of temperature than provided by the current generation of RCMs.

In conclusion, the projected warming of climate is likely to be mostly beneficial to apple growing in Finland before the mid-century, as found in eastern Canada by Rochette et al. (2004) and for Great Lakes area in USA by Winkler et al. (2002), though exact comparisons between the studied regions cannot be made because the regional climates of the regions are different. The warming allows a wider selection of cultivars to home gardens, more productive cultivars in the south for commercial production and expansion of production in the south-eastern lake area. To introduce new cultivars and expand commercial production, winter hardiness and yield characteristics need to be tested at potential production sites. To increase the value of commercial production in the south, a programme for breeding and testing cultivars of late winter type should be initiated, with the aim of developing cultivars that produce fruits storable into spring, longer than any of the currently grown cultivars
(Kinnanen et al. 2007). Adaption to climate change emphasizes existing general breeding targets which include low sensitivity to temperature fluctuation in winter, late flowering, frost tolerance of flowers, and better resistance to canker. The process from breeding to establishing actual orchards takes 15 to 20 years, and hence, breeding targets should be set within the next five years. Screening of the existing cultivars and rootstocks at sites where they have not been tested could start within 10 to 15 years, because the testing requires, at least, 5 to 10 years, or even more if no cold winters occur within that period.

Acknowledgements. We thank Mr. Hannu Ojanen for producing the figures.

\section{References}

Atkins, T.A. \& Morgan, E.R. 1990. Modelling the effects of possible climate change scenarios on the phenology of New Zealand fruit crops. Acta Horticulturae 276: 201-208.

Austin, P.T. \& A.J. Hall, A.J. 2001. Temperature Impacts on Development of Apple Fruits. In: Warrick, R.A., Kenny, G.J. \& Harman, J.J. (eds.) The Effects of Climate Change and Variation in New Zealand An Assessment Using the CLIMPACTS System. International Global Change Institute (IGCI), The University of Waikato. $127 \mathrm{p}$.

Caprio, J.M. \& Quamme, H.A. 1999. Weather conditions associated with apple production in the Okanagan Valley of British Columbia. Canadian Journal of Plant Science 79: 129-137.

Coleman, W.K. 1992. A proposed winter-injury classification for apple trees on the northern fringe of commercial production. Canadian Journal of Plant Science 72: 507-516.

Eccel, E., Rea, R. \& Caffarra, A. 2009. Risk of spring frost to apple production under future climate scenarios: the role of phenological acclimation. International Journal of Biometeorology 53: 273-286.

Heide, O.M. \& Prestrud, A.K. 2005. Low temperature, but not photoperiod, controls growth cessation and dormancy induction and release in apple and pear. Tree Physiology 25: 109-114.

Howell, G.S. \& Weiser, C.J. 1970a. Similarities between the control of flower initiation and cold acclimation in plants. HortScience 5: 18-20.

Howell, G.S. \& Weiser, C.J. 1970b. Fluctuations in the cold resistance of apple twigs during spring dehardening. Journal of American Society for Horticultural Science 95: 190-192. 
Kaukoranta, T. et al. Climatic potential and risks for apple growing

Hänninen, H. 2006. Climate warming and the risk of frost damage to boreal forest trees: identification of critical ecophysiological traits. Tree Physiology 26:889-898.

Hänninen, H. \& Kramer, K. 2007. A framework for modelling the annual cycle of trees in boreal and temperate regions. Silva Fennica 41: 167-205.

IPCC. 2007. Climate Change 2007: The Physical Science Basis. Contribution of Working Group I to the Fourth Assessment Report of the Intergovernmental Panel on Climate Change. Solomon, S., Qin, D., Manning, M., Chen, Z., Marquis, M., Averyt, K.B., Tignor, M. \& Miller, H.L. (eds.) Cambridge University Press, Cambridge, UK and New York, NY, USA, 996 p.

Jylhä, K., Tuomenvirta, H. \& Ruosteenoja, K. 2004. Climate change projections for Finland during the 21st century. Boreal Environmental Research 9: 127-152.

Kaas, E. \& Frich, P. 1995. Diurnal temperature range and cloud cover in the Nordic countries: observed trends and estimates for the future. Atmospheric Research 37: $211-228$

Ketchie, D.O. \& Beeman, C.H. 1973. Cold acclimation in 'Red Delicious' apple trees under natural conditions during four winters. Journal of American Society for Horticultural Science 98: 257-261.

Kinnanen, H., Tahvonen, R. \& Ylämäki, A. 2007. Lajikkeisto. Omenan viljely, Puutarhaliiton julkaisuja nro 345: 180 -208 (In Finnish).

Khanizadeh, S. 2007. Cultural and environmental factors associated with winter injury to apple in Northern Eastern Canada. International Journal of Fruit Science 7: 85-100.

Kjellström, E., Bärring, L., Gollvik, S., Hansson, U., Jones, C., Samuelsson, P., Rummukainen, M., Ullerstig, A., Willén, U. \& Wyser, K. 2005. A 140-year simulation of European climate with the new version of the Rossby Centre regional atmospheric climate model (RCA3). SMHI Reports Meteorology and Climatology No 108, 54 p.

Kjellström, E., Bärring, L., Jacob, D., Jones, R., Lenderink, G. \& Schär, C. 2007. Modelling daily temperature extremes: recent climate and future changes over Europe. Climatic Change 81: 249-265.

Kronenberg, H.G. 1979. Apple growing potentials in Europe 1. The fulfilment of the cold requirement of the apple tree. Netherlands Journal of Agricultural Science 27: 131-137.

Legave, J.M, Farrera, I, Almeras, T., Santamaria, P. \& Calleja, M. 2008. Selecting models of apple flowering time and understanding how global warming has had an impact on this trait. Journal of Horticultural Science and Biotechnology 83: 76-84.

Lindén, L., Rita, H. \& Suojala, T. 1996. Logit Models for Estimating Lethal Temperatures in Apple. HortScience 31: $91-93$.

Lindén, L. 2001. Re-analyzing historical records of winter injury in Finnish apple orchards. Canadian Journal of Plant Science 81: 479-485.

Linkosalo, T., Häkkinen, R. \& Hänninen, H. 2006. Models of the spring phenology of boreal and temperate trees: is there something missing? Tree Physiology 26:1165-1172.

Menzel, A., Sparks, T.H., Estrella, N., Koch, E., Aasa, A., Ahas, R., Alm-Kubler, K., Bissolli, P., Braslavska, O., Briede, A., Chmielewski, F.M., Crepinsek, Z., Curnel,
Y., Dahl, A., Defila, C., Donnelly, A., Filella, Y., Jatczak, K., Mage, F., Mestre, A., Nordli, ., Penuelas, J., Pirinen, P., Remisova, V., Scheifinger, H., Striz, M, Susnik, A.., Van Vliet, A.J.H., Wielgolaski, F..E., Zacht, S. \& Zust, A. 2006. European phenological response to climate change matches the warming pattern. Global Change Biology 12: 1969-1976.

Nakicenovic, N., Alcamo, J., Davis, G., de Vries, B., Fenhann, J., Gaffin, S., Gregory, K., Grübler, A., Yong Jung, T., Kram, T., Lebre La Rovere, E., Michaelis, L., Mori, S., Morita, T., Pepper, W., Pitcher, H., Price, L., Riahi, K., Roehrl, A., Rogner, H.-H., Sankovski, A., Schlesinger, M., Shukla, P., Smith, S., Swart, R., van Rooijen, S., Victor, N. \& Dadi, Z. 2000. Emission scenarios. A special report of working group III of the intergovernmental panel on climate change. Cambridge University Press, $599 \mathrm{p}$.

Repo,T, Hanninen, H, Kellomäki, S. 1996. The effects of long-term elevation of air temperature and $\mathrm{CO}_{2}$ on the frost hardiness of Scots pine. Plant Cell \& Environment 19:209-216.

Richardson, E.A., Seeley, S. D. \& Walker, D. R. 1974. A model for estimating the completion of rest for 'Redhaven' and 'Elberta' peach trees. HortScience 9: 331332.

Rochette, P., Bélanger, G., Castonguay, Y., Bootsma, A. \& Mongrain, D. 2004. Climate change and winter damage to fruit trees in eastern Canada. Canadian Journal of Plant Science 84: 1113-1125.

Rosenzweig, C., G. Casassa, D.J. Karoly, A. Imeson, C. Liu, A. Menzel, S. Rawlins, T.L. Root, B. Seguin, P. Tryjanowski, 2007. Assessment of observed changes and responses in natural and managed systems. Climate Change 2007: Impacts, Adaptation and Vulnerability. Contribution of Working Group II to the Fourth Assessment Report of the Intergovernmental Panel on Climate Change, M.L. Parry, O.F. Canziani, J.P. Palutikof, P.J. van der Linden \& C.E. Hanson, (eds.), Cambridge University Press, Cambridge, UK, 79-131.

Roeckner, E., Bengtsson, L., Feicther, J., Lelieveld, J. \& Rodhe, H., 1999. Transient climate change simulations with a coupled atmosphere-ocean GCM including the tropospheric sulfur cycle. Journal of Climate 12: 3004-3032.

Stanley, C.J., Lupton, G.B, McArtney, S., Cashmore, W.M. \& De Silva, H.N. 2000. Towards understanding the role of temperature in apple fruit growth responses in three geographical regions within New Zealand. Journal of Horticultural Science \& Biotechnology 75: 413-422.

Säkö J. \& Pessala, T. 1967. Injuries in Finnish orchards caused by winter 1965-66. Annales Agriculturae Fenniae 6: 53-62.

Taylor, G., Tallis, M.J., Giardina, C.P., Percy, K.E., Miglietta, F., Gupta, P.S., Gioli, B., Calfapietra, C., Gielen, B., Kubiske, M.E., Scarascia-Mugnozza, G.E., Kets, K., Long, S.P. \& Karnosky, D.F. 2008. Future atmospheric CO2 leads to delayed autumnal senescence. Global Change Biology 14: 264-275.

Tumanov, I.I., Kuzina, G.V., Karnikova, L.D. \& Khvalin, N.N. 1972. Effect of vegetation time on ability of woody plants to increase their frost resistance during the process of hardening. Soviet Plant Physiology 19: 31-39.

Tuomenvirta, H. 2004. Reliable estimation of climatic vari- 


\section{AGRICULTURAL AND FOOD SCIENCE}

Vol. 19 (2010): 144-159.

ations in Finland. Diss. University of Helsinki. 79 p. Finnish Meteorological Institute Contributions No. 43.

Tuomenvirta, H., Alexandersson, H., Drebs, A., Frich, P. \& Nordli, P.E. 2000. Trends in Nordic and Arctic Temperature Extremes and Ranges. Journal of Climate 13: 977-990.

Uppala, S. M., Kållberg, P.W., Simmons, A.J., Andrae, U., da Costa Bechtold, V., Fiorino, M., Gibson, J.K., Haseler, J., Hernandez, A., Kelly, G.A., Li, X., Onogi, K., Saarinen, S., Sokka, N., Allan, R.P., Andersson, E., Arpe, K., Balmaseda, M.A., Beljaars, A.C.M., van de Berg, L., Bidlot, J., Bormann, N., Caires, S., Chevallier, F., Dethof, A., Dragosavac, M., Fisher, M., Fuentes, M., Hagemann, S., Holm, E., Hoskins, B.J., Isaksen, L., Janssen, P.A.E.M., Jenne, R., McNally, A.P., Mahfouf, J.-F., Morcrette, J.-J., Rayner, N.A, Saunders, R.W., Simon, P., Sterl, A., Trenberth, K.E., Untch, A., Vasiljevic, D., Viterbo P. \& WoolIen, J. 2005. The ERA-40 Re-analysis. Quarterly Journal of Royal Meteorological Society 131: 2961-3012.
Wayne, P.M., Reekie, E.G. \& Bazzaz, F.A. 1998. Elevated $\mathrm{CO} 2$ ameliorates birch response to high temperature and frost stress: implications for modelling climate-induced geographic range shifts. Oecologia. 114: 335-342.

Winkler, J.A., Andresen, J.A., Guentchev, G. \& Kriegel, R.D. 2002. Possible impacts of projected temperature change on commercial fruit production in the Great Lakes region. Journal of Great Lakes Research 28: 608-625.

Wolfe, D.W., Schwartz, M.D., Lakso, A.N., Otsuki, Y., Pool R.M. \& Shaulis, N.J., 2005. Climate change and shifts in spring phenology of three horticultural woody perennials in north-eastern USA. International Journal of Biometeorology 49: 303-309.

Ylämäki, A. \& Tahvonen, R. 1998. Omenalajikkeiden sadon valmistumista voi arvioida lämpösumman avulla. Puutarha \& Kauppa 2, 35: 4-5 (In Finnish). 